\title{
LEPTOSPIRAL FEVER
}

\author{
M. R. P. Hall, B.M.(Oxon.), M.R.C.P., M.R.C.P.E. \\ Senior Medical Registrar, The Radcliffe Infirmary, Oxford
}

THE first reported case of human leptospirosis was reported by Weil in 1886 . This was followed by the discovery of $L$. icterohamorrhagiae by Inada, Ido, Hoki, Kaneko and Ito in I9I6. Since then some 40 separate antigenic types have been identified by serological methods (Broom, I953). Many of these 'serotypes' have related antigenic qualities and may, therefore, be assembled for convenience into four main sero-groups. The number of distinct serotypes in any one area varies enormously and some serotypes may be world wide in their distribution, while others are localized to one country or area. In Great Britain only two types, L. icterohamorrhagiae and $L$. canicola, have so far been discovered. These respectively give rise to classical Weil's disease, often a very serious illness, and to canicola fever, usually a very mild illness. Sometimes, however, the difference between these two types of leptospiral fever may be difficult to recognize clinically and can only be determined by serological or bacteriological methods.

\section{Case Report (RI No. 262322)}

Mr. J. G. was admitted to the Radcliffe Infirmary complaining of muscular pains in the thighs and legs, drowsiness and having passed no urine for 3 days. On enquiry he said he had had two dogs, both of which had been ill recently. One of these had died some $5 \frac{1}{2}$ months before of, he thought, arsenic poisoning, though 5 other dogs in the village had died of a similar complaint. The other dog, a puppy, had been ill more recently and had scratched him about 3 weeks before. One week before admission, after a strenuous day gardening, he felt very thirsty and noticed some aching pain in the thighs. This wore off gradually during the next 48 hours, though he continued to feel unwell. Three days later he had a rigor and when seen by his doctor was found to be cyanosed and dyspnœic with signs of consolidation at the left lung base. A provisional diagnosis of left lower lobe pneumonia was made and he was admitted to the local hospital and given intramuscular penicillin with sulphatriad by mouth. Rigors recurred and he was occasionally delirious during that day, but the next day he was better, being afebrile and quite rational. His urinary output, however, diminished and it was noticed that he was jaundiced. The oliguria persisted and catheterization 48 hours later produced only $15 \mathrm{ml}$. of dark urine. During this period his condition deteriorated and he gradually became more drowsy. He was, therefore, transferred, his practitioner's diagnosis being 'the canine variety of Weil's Disease.'

The veterinary surgeon was, therefore, contacted and he stated that he had no doubt that the first dog had died from a leptospiral infection. The second dog, however, had now recovered and had not certainly had a leptospiral infection, though this was possible.

\section{Examination}

Well built, mildly jaundiced man. Very drowsy, but quite orientated. Temperature $99.0^{\circ} \mathrm{F}$. Eyes slightly $N$ suffused and showing well marked icterus. Some iv purpura over buttocks, trunk and thighs. Pulse 82/minute. B.P. 100/80. All other systems normal.

\section{Special Investigations}

Blood: Hæmoglobin $85 \%$. W.B.C. 10,000/cu. mm. Platelets $24,000 / \mathrm{cu}$ mm. E.S.R. II $6 \mathrm{~mm}$. in I hour (Westergren). Film-neutrophil leucocytosis. Red $\vec{\bullet}$ cells normal. Platelets reduced. One-stage prothrombig o time-ratio r.o.

Urine: Sp. Gr. 1010. Protein-more than I,00B $\mathrm{mg}$./ $100 \mathrm{ml}$. Numerous red cells. Moderate numbers of pigmented granular and some hyaline casts. Chemicall test for blood strongly positive. Urea $=7 \mathrm{~g}$. $/ 1$. Bilirubin present. Culture-very light growth of proteus mirabilis and $B$. coli.

Blood chemistry; Blood urea - $135 \mathrm{mg}$./100 ml. Plasma sodium I $29 \mathrm{mEq}$./1. Plasma chloride $93 \mathrm{mEq}$. $/ \mathrm{l}$. Plasma bicarbonate $16 \mathrm{mEq} / 1$. Plasma potassium 4.6 mEq./l. Plasma proteins, total $5.6 \mathrm{~g}$./ $/ 00 \mathrm{ml}$., albumin $2.9 \mathrm{~g}$. $/ \mathrm{r} 00 \mathrm{ml}$. Plasma bilirubin $2.7 \mathrm{mg}$./ roo ml. Blood plasma flocculation tests: Thymol turbidity and colloidal gold negative on three occasions. $\mathrm{CSF}$ protein $30 \mathrm{mg}$./100 ml. Cells 7, 6 lymphocytes. ECG normal.

\section{Progress}

This can be seen from Fig. I. His renal failure was treated by fluid restriction to approximately I litre per day in the form of weak tea and fruit juice. To this was added about $400 \mathrm{~g}$. of glucose. During the first few days prostration was marked and he was depressed and very apprehensive. When his diuresis commenced fluids were increased and he became more cheerful. A potassium supplement was given from the tenth day and by the thirteenth he was taking a light diet containing about $20 \mathrm{~g}$. protein. From then onward his recovery was uneventful. His urine was free of albumin by the twelfth day and his blood urea had fallen to $5 \mathrm{I} \mathrm{mg}$./100 $\mathrm{ml}$. by the fifteenth day. $\mathrm{He}$ was discharged 37 days after admission quite well though still feeling weak. 


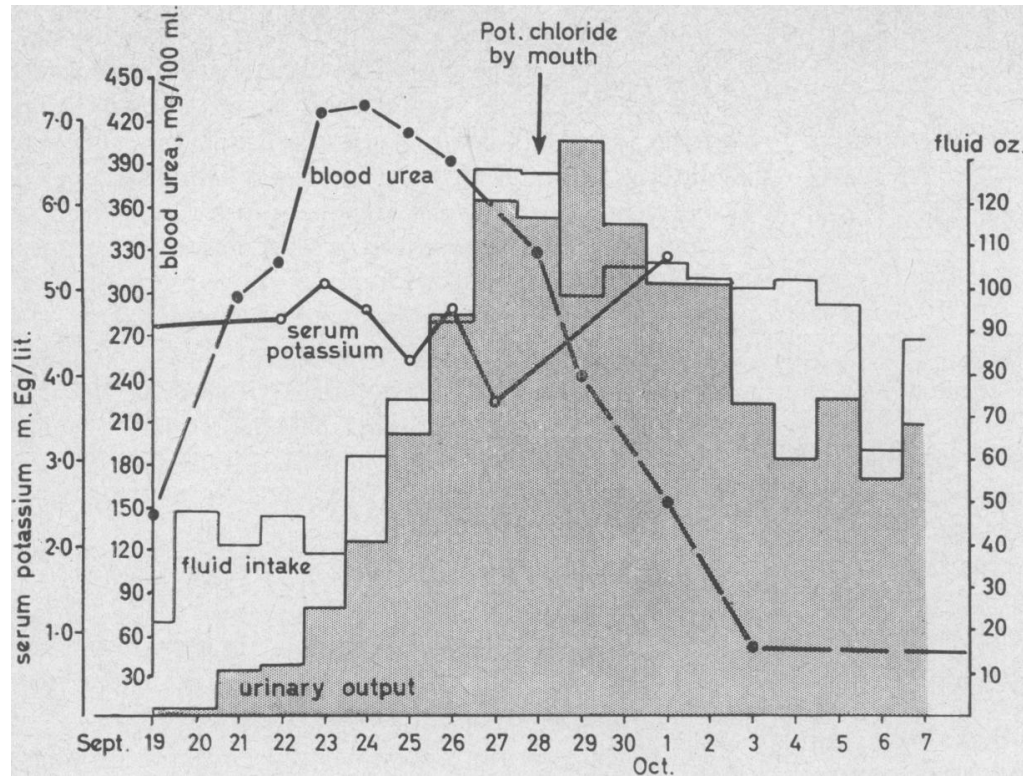

FIG. 1.-Showing the progress of disease, comparing fluid intake with urinary output and blood urea.

\section{Discussion}

This patient presented in a manner very similar to that of classical Weil's disease and while his general practitioner was quite correct in his provisional diagnosis of canicola fever it is very unusual for this condition to progress to anuria and renal failure in this manner. Canicola fever is usually a mild condition which commonly presents with the signs of an aseptic meningitis, which occurs in over $75 \%$ of patients (Broom, $195 \mathrm{I}$ ). Other fairly common signs and symptoms are injection of the eyes, muscle tenderness and albuminuria; casts in the urine, jaundice and hæmorrhages are relatively uncommon, occurring in under $20 \%$ of patients. In Weil's disease it is the extent of renal involvement which usually determines the outcome of the attack and this often goes hand in hand with jaundice. The incidence of jaundice varies in Weil's disease from between 35 to $90 \%$ according to various authors (Kalz, 1957). In canicola fever, however, jaundice occurs in a much lower percentage, e.g. $18 \%$ of 54 cases (Broom, 1951), $13 \%$ of 173 cases (Rosenberg, 1951). Renal involvement is well recognized, though this is usually mild and rarely causes severe illness. According to Rosenberg, a mild acute nephritis as evidenced by oliguria, albuminuria and microscopic hæmaturia may occur in $39 \%$ of cases, but albuminuria lasting longer than one month occurs in only $10 \%$ of patients and the blood urea rarely rises to over $60 \mathrm{mg} . / 100 \mathrm{ml}$., though in one case (Bukh, 1940) it rose to $140 \mathrm{mg} / 100 \mathrm{ml}$. on the 63rd day of the illness. So far only two fatal cases of canicola fever have been reported (Weetch et al., 1949, and Woolf et al., 195I) and in both cases there was pre-existing renal disease The considerable rise in the blood urea in the case described is, therefore, most unusual. In this case there seems to have been no pre-existing renal disease present. It is possible, in view of the pyuria and positive urine culture, that this patient may have a chronic pyelonephritis, but against this is the remarkably rapid recovery of renal function, the blood urea falling from $430 \mathrm{mg}$./ $100 \mathrm{ml}$. to $51 \mathrm{mg} . / 100 \mathrm{ml}$. in nine days, and the fact that his urine was free of albumin 12 days after admission. It was also reported normal two months after discharge. A further interesting point in this case is the thrombocytopenia, though hæmorrhage and bruising are, of course, well known features of Weil's disease.

There can be little doubt in this case that the diagnosis was correct. The portal of entry for the organism was presumably the skin, via the scratch received from an ill dog. The incubation time, I4 days from the time of the scratch to the first symptoms, is exactly right. The premonitory symptoms followed by a rigor and respiratory signs with the initial tentative diagnosis of pneumonia are quite classical. The clinical picture is also supported by the rising leptospiral agglutination titre (Table $I$ ). In this connection it seems very probable that owing to the slow rise in titre a number of cases of the milder type are missed because they have clinically recovered before a diagnostic level is reached. 
TABLE I

Leptospiral Agglutinations

\begin{tabular}{|c|c|c|}
\hline & $\begin{array}{c}\text { L. Ictero- } \\
\text { hamorrhagiae }\end{array}$ & L. Canicola \\
\hline On admission & Negative & $\begin{array}{l}\text { Trace } 1 / 10 \\
\text { Negative } 1 / 30\end{array}$ \\
\hline $\begin{array}{l}\text { I week after } \\
\text { admission }\end{array}$ & $\begin{array}{c}\text { Negative } \\
1 / 10-1 / 3,000\end{array}$ & $\begin{array}{l}\text { Positive } I / r, 000 \\
\text { Negative } I / 3,000\end{array}$ \\
\hline $\begin{array}{l}\text { weeks after } \\
\text { admission }\end{array}$ & $\begin{array}{l}\text { Positive } 1 / 100 \\
\text { Negative } 1 / 300\end{array}$ & $\begin{array}{l}\text { Positive } 1 / 1,000 \\
\text { Negative } 1 / 3,000\end{array}$ \\
\hline
\end{tabular}

$\mathrm{Kalz}$, in her review of leptospirosis, emphasizes the great variety in the clinical response to infections by all types of leptospiræ. Most authors tend to stress the point that $L$. canicola ir.f sctions present as an aseptic meningitis (Broom, 1953, Gear et al., 1958). L. icterohamorrhagiae infections may also present in this way (Buzzard and Wylie, 1947) though usually they present in a similar manner to the patient described above, and often run a more severe and alarming course. Other leptospiral infections may present in a variety of ways, usually as short febrile illnesses with or without meningeal involvement and often with respiratory tract involvement so that they are misdiagnosed as atypical pneumonia, virus pneu- monia, or influenza. These have given rise to a plethora of names such as swineherd fever, mud fever, Japanese seven-day fever, Fort Bragg fever, etc. This undoubtedly leads to confusion and as some degree of para-agglutination exists between $L$. icterohamorrhagiae and $L$. canicola as well as other serotypes it would seem that a good case can be made out for a simple clinical classification. The term leptospiral fever seems the most suitable, but if the eponym 'Weil's disease' is retained then it should be reserved for the 'severe', 'malignant' or 'icteric' form of the disease, regardless of whether it is caused by $L$. icterohamorrhagia, $L$. canicola or even $L$ hebdomadis.

\section{Summary}

I. A severe case of canicola fever simulating Weil's disease is described. Mild cases may not be so uncommon as would appear.

2. The literature is briefly reviewed and a clinical classification of leptospiral infections is suggested in the hope that this will avoid confusion.

I should like to thank Dr. P. C. Mallam for permission to report this case and Miss McLarty for the diagram.

\section{REFERENCES}

Broom, J. C. (195 I): Leptospirosis in England and Wales, Brit. med. F., ii, 689.

(1953): Leptospirosis in Tropical Countries, Trans. roy. Soc. trop. Med. Hyg., 47, 273.

Buкh, N. (1940): Et tilfælde af Leptospirosis Canicolaris med udtalt nephropathi, Ugeskr. Laeg., roz, i 142.

Buzzard, E. M., and Wylie, J. A. H. (1947): Meningitis Leptospirosa, Lancet, ii, 417.

Dhont, C. M., Klarenbeek, A., Schïffner, W. A. P., and Voet, J. (1934): De Leptospiroses bij den hond en de beteekenis der Leptospira Canicola, Ned. T. Geneesk., 73, 5 I 78.

Gear, J., Wolstenholme, B., Jackson, A., Chesler, E., and Brueckner, R. M. (1958): Leptospirosis in South Africa S. Afr. med. F., 32, 94.

INADA, R., IDO, Y., HoKI, R., Kaneko, R., and Ito, H. (I9I6): Ætiolozy, Mode of Infection and Specific Therapy of Weil's Disease, F. exp. Med. Hyg., 23, 377.

Kalz, G. (1957): The Human Leptospiroses, Amer. F. med. Sci., 233, 320.

Rosenberg, B. L. (r95I): Canicola Fever: Review, with Report of Two New Cases, Amer. F. Med., rx, 75.

WEIL, H. A. (1886): Ueber eine eigenthümliche, mit Milztumour, Icterus und Nephritis einhergehende, acute Infectionskraukheit, Dtsch. Arch. klin. Med., 39, 209.

Weetch, R. S., Colquhoun, H., and Broom, J. C. (r949): Fatal Human Case of Canicola Fever, Lancet, i, 9o6.

Woolff, J. W., Van Dam, R., and Menkenhoff, J. E. (r95I): The First Known Fatal Case of Canicola Fever, Ibid., i, I 100. 